\title{
Determinants of corporate dividend policy: evidence from romanian listed companies
}

\author{
Ciprian Cristea $^{{ }^{*}}$, Maria Cristea $^{2}$ \\ ${ }^{1}$ Technical University of Cluj-Napoca, Faculty of Electrical Engineering, ciprian.cristea@emd.utcluj.ro, Romania \\ ${ }^{2}$ Technical University of Cluj-Napoca, Faculty of Electrical Engineering, fagarasan_maria@yahoo.com, Romania
}

\begin{abstract}
Although there is a vast literature that has investigated the dividend policies of firms from developed countries, relatively little research has been published exploring the dividend policies of firms from emerging countries. The literature regarding establishing the relationship between dividend policy and the attributes of non-financial companies listed on Romanian stock market, to the best of our knowledge, remains inexistent. The aim of this study is to identify the main factors influencing dividend policy for the non-financial companies listed on the Bucharest Stock Exchange for a period of ten years from 2007 to 2016. In order to achieve this aim, panel data were collected from the listed companies' reports and financial statements. The study reveals that dividend policy is positively related to corporate profitability and liquidity and negatively associated with leverage, size, growth, and the state of the economy.
\end{abstract}

\section{Introduction}

The dividend policy is one of the most researched topics in corporate finance over the past decades. Dividend policy represents the set of guidelines a firm uses to dispose how much of its financial resources will payout to its shareholders, when it is not required by law, as mentioned by K. Kato, U. Loewenstein, W. Tsai [1]. M. Miller and F. Modigliani [2], pioneers in this field, demonstrate that dividend payments have no effect on company value and the payout ratios should not matter under perfect capital market assumptions. Yet, in the real world where markets that are far from being perfect, the irrelevance theory proposed by M. Miller, F. Modigliani [2] is no more an acceptable answer.

Dividend policy continues to retain the interest of academics, creditors, management, and shareholders. The importance attached to this topic arises from its interconnection with other corporate decisions, such as financing and investments, and its effect on shareholders' wealth and on the whole economy I. Jabbouri [3]. Dividend income represents a part of the national income, hence, it helps in understanding the overall performance of the economy D.L. Papadopoulos, P.D. Charalambidis [4]. Choosing the dividend policy is a strategic decision, generally made by top managers, which requires the final approval of the board of directors. Dividends account for roughly thirty percent of the corporate profits of publicly-traded firms around the world A. Fatemi, R. Bildik [5]. The dividend policy literature is vast and contains many hypotheses, and explanations for dividends, financial academics proposing many competing theories about why firms pay, or do not pay, dividends and, despite extensive debate and ample empirical research, no universally accepted explanation is achieved on the actual motivation for paying dividends to be published H.K. Bakera, E. Kilincarslanb, A.H. Arsalc [6].

The continuous growth of empirical studies dealing with the firm's payout policy identifies mixed results. E.F. Fama, K.R. French [7] show a decrease in the propensity to pay dividends by US companies during 1978-1999. Similar findings are recorded for six developed economies during 1994-2002 D.J. Denis, I. Osobov [8], in the UK L. Renneboog, G. Trojanawski [9], for firms in the EU for 1989-2005 H. Von Eije, W.L. Megginson [10], for companies in India for 1991-2001 Y.S. Reddy, S. Rath [11], for a couple of companies from twenty-three countries S.P. Ferris, N. Jayaraman, S. Sabherwal [12], for a large sample of firms in 33 countries A. Fatemi, R. Bildik [5]. H. DeAngelo, L. DeAngelo, D.J. Skinner [13] contradict these findings, showing that dividends paid by US industrial firms actually increased between 1978 and 2000. B. Julio, D. Ikenberry [14] support H. DeAngelo, L. DeAngelo, D.J. Skinner [13] conclusions with regard to the US companies. R. Bildik, A. Fatemi, I. Fooladi [15] compare the dividend payout behavior of US firms with

\footnotetext{
Corresponding author: ciprian.cristea@emd.utcluj.ro
} 
those of firms in 32 other countries for the period between 1985-2011 and found that the proportion of firms that pay dividends in the US is smaller than in the rest of the world.

G. Bekaert, C.R. Harvey [16] mention that corporate finance models are developed taking into account that are consistent with developed countries, which may cause that these models fail when tested in emerging ones. T. Lagoarde-Segot [17] specifies that managerial models are developed in Western countries, and when are applied in a different institutional context become poor guides to business decisions. Dividend policy is a topic of ongoing debate in both developed H.K. Baker, G.E. Farrelly, E.T. Veit [18] and developing countries A. Hafeez, Y.J. Attiya [19].

In this paper, we investigate the relationship between dividend policy and the attributes of non-financial companies listed on the Bucharest Stock Exchange Market for a period of ten years from 2007 to 2016. In this study, panel data analysis is applied to investigate the determinants of dividend policies of the Romanian companies mentioned above. This research has important implications for both theory and practice. No study, to the best of our knowledge, has examined the determinants of dividend policy on the Romanian market. Our findings have implications for corporate finance and governance theories, academics, investors, regulators, and policymakers in emerging markets.

The rest of the paper is organized as follows: in the next paragraph the methodology is described, furthermore, the empirical results are presented in the third section and, finally, the last section summarizes the conclusions.

\section{Methodology}

The objective of this paper is to explore dividend policy in Romania and identify its main determinants. In order to test the impact on dividend policy of the most important factors detected in literature, this study uses panel data analysis. These factors include: size of the firm, financial leverage, growth, current profitability, liquidity, and the state of the economy. These factors were chosen due to their influence on dividend behavior in developed and emerging markets. The financial data were collected manually from the annual reports and financial statements of Romanian non-financial firms listed on the Bucharest Stock Exchange Market over the period 2007-2016, thus having 701 complete companyyears observations.

In order to measure the amount of dividend payment, we used the annual cash dividend per share over the book value of assets per share (Div) of a company, following the case presented by K. Li, X. Zhao [20], Y. Grinstein, R. Michaely [21]. The dependent variable is cash dividend over book value of assets.

Most of the independent variables were intensively used in similar previous reported empirical work: size of the firm, financial leverage, growth, current profitability, liquidity, and the state of the economy. Firm size (Size) is measured as natural logarithm of total assets, total book value of debt divided by total assets (Leverage) will proxy for financial leverage. For the growth opportunities, annual growth in sales is used as a proxy (Growth). In order to quantify the company current profitability, return on equity is used as a proxy (Profitability). Return on equity is a firm's net income divided by its shareholder's equity. Quick or acid test ratio shows the ratio of cash and other liquid resources of a company in comparison to its current liabilities, being employed as a measure of liquidity (Liquidity). Finally, gross domestic product growth rate $(G D P)$ will be used to control for the state of the economy.

In order to examine the impacts of these indicators (size of the firm, financial leverage, growth, current profitability, liquidity, and the state of the economy) on dividend policy, the study uses a panel analysis. For estimating the regression equation, the ordinary least square (OLS) method was used. The basic regression takes the following form:

$$
\begin{aligned}
& \text { Div }_{\text {it }}=\alpha_{i}+\beta_{1} \cdot \text { Size }_{i t}+\beta_{2} \cdot \text { Leverage }_{i t}+\beta_{3} \cdot \text { Growth }_{i t}+ \\
& \beta_{4} \cdot \text { Profitability }_{\text {it }}+\beta_{5} \cdot \text { Liquidity }_{i t}+\beta_{6} \cdot \text { GDP }+\mu_{i t}
\end{aligned}
$$

In this equation, the subscript $t$ represents the timeseries dimension and $i$ denotes the cross-sectional dimension.

\section{Results}

Table 1 presents the descriptive statistics of the dependent and independent variables used in the empirical analyses. The annual cash dividend per share over the book value of assets per share of a company is on average 0.055 which is higher that of Argentinian (0.034) and Brazilian (0.027) companies J. Benavides, L. Berggrun, H. Perafan [22]. Average leverage is lower than the average corporate indebtedness for the Argentinan (0.449) and Brazilian (0.539) companies J. Benavides, L. Berggrun, H. Perafan [22].

Table 1. Descriptive statistics of variables

\begin{tabular}{cccc}
\hline \hline & Mean & Median & $\begin{array}{c}\text { Standard } \\
\text { deviation }\end{array}$ \\
\hline Div & 0.055 & 0.032 & 0.079 \\
Size & 17.802 & 17.556 & 1.983 \\
Leverage & 0.217 & 0.153 & 0.187 \\
Growth & 0.137 & 0.034 & 0.715 \\
Profitability & 6.968 & 5.087 & 7.473 \\
Liquidity & 5.577 & 2.08 & 13.933 \\
GDP & 4.822 & 10.05 & 32.598
\end{tabular}

The dividend policy trend is shown in fig. 1. As revealed in fig. 1, an upward trend is evident during the global financial crisis years. 


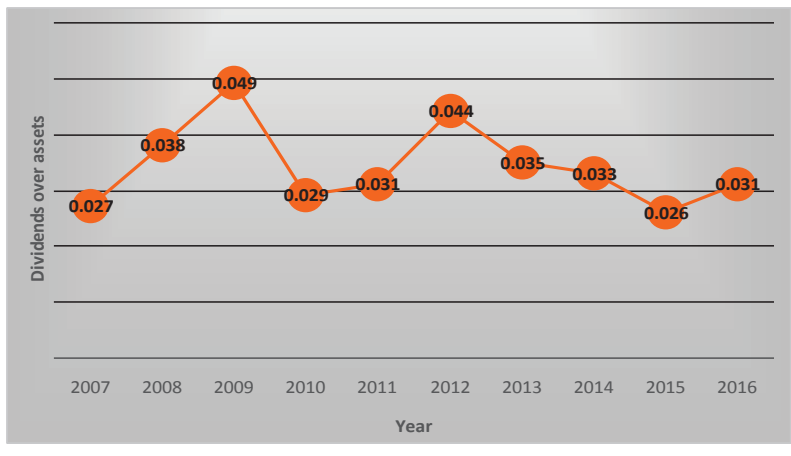

Fig. 1. Dividend policy trend during 2007-2016

It can be noticed that the values for annual cash dividend per share over the book value of assets per share were fairly stable over the study period, the lowest median is 0.026 in 2015 and the highest is 0.049 in 2009.

In Table 2, we present the Pearson correlation coefficients for the variables used in this paper.

Table 2. Pearson correlation coefficients for the variables

\begin{tabular}{|c|c|c|c|c|c|c|c|}
\hline & Div & Size & $\begin{array}{l}\text { Leverag } \\
\mathrm{e}\end{array}$ & Growth & $\begin{array}{l}\text { Liquid } \\
\text { ity }\end{array}$ & $\begin{array}{l}\text { Profita- } \\
\text { bility }\end{array}$ & $\begin{array}{c}\mathrm{G} \\
\mathrm{DP}\end{array}$ \\
\hline $\begin{array}{l}\text { Div } \\
\text { Sig. (2- } \\
\text { tailed) }\end{array}$ & $\begin{array}{l}1 \\
-\end{array}$ & & & & & & \\
\hline $\begin{array}{l}\text { Size } \\
\text { Sig. (2- } \\
\text { tailed) }\end{array}$ & $\begin{array}{l}- \\
0.1324 \\
(0.00)\end{array}$ & $\begin{array}{l}1 \\
-\end{array}$ & & & & & \\
\hline $\begin{array}{l}\text { Leverage } \\
\text { Sig. (2- } \\
\text { tailed) }\end{array}$ & $\begin{array}{l}- \\
0.1318 \\
(0.00)\end{array}$ & $\begin{array}{l}0.1134 \\
(0.002)\end{array}$ & $\begin{array}{l}1 \\
-\end{array}$ & & & & \\
\hline $\begin{array}{l}\text { Growth } \\
\text { Sig.(2- } \\
\text { tailed) }\end{array}$ & $\begin{array}{l}- \\
0.0141 \\
(0.70)\end{array}$ & $\begin{array}{l}- \\
0.0219 \\
(0561)\end{array}$ & $\begin{array}{l}0.1 \\
(0.008)\end{array}$ & $\begin{array}{l}1 \\
-\end{array}$ & & & \\
\hline $\begin{array}{l}\text { Liquidity } \\
\text { Sig. (2- } \\
\text { tailed) }\end{array}$ & $\begin{array}{l}0.0903 \\
(0.01)\end{array}$ & $\begin{array}{l}- \\
0.0856 \\
(0.023)\end{array}$ & $\begin{array}{l}-0.3038 \\
(0.0000)\end{array}$ & $\begin{array}{l}0.1326 \\
(0.000)\end{array}$ & $\begin{array}{l}1 \\
-\end{array}$ & & \\
\hline $\begin{array}{l}\text { Profitability } \\
\text { Sig. (2- } \\
\text { tailed) }\end{array}$ & $\begin{array}{l}0.5258 \\
(0.00)\end{array}$ & $\begin{array}{l}- \\
0.1083 \\
(0.004)\end{array}$ & $\begin{array}{l}0.1698 \\
(0.0000)\end{array}$ & $\begin{array}{l}0.0905 \\
(0.0165)\end{array}$ & $\begin{array}{c}-0.0674 \\
(0.0742)\end{array}$ & $\begin{array}{l}1 \\
-\end{array}$ & \\
\hline $\begin{array}{l}\text { GDP } \\
\text { Sig. (2- } \\
\text { tailed) }\end{array}$ & $\begin{array}{l}0.0144 \\
(0.701)\end{array}$ & $\begin{array}{l}0.0629 \\
(0.095)\end{array}$ & $\begin{array}{l}0.0253 \\
(0.502)\end{array}$ & $\begin{array}{l}0.1264 \\
(0.000)\end{array}$ & $\begin{array}{l}-0.0512 \\
(0.174)\end{array}$ & $\begin{array}{l}0.1123 \\
(0.0029)\end{array}$ & $\begin{array}{l}1 \\
-\end{array}$ \\
\hline
\end{tabular}

According to our assumption and to the results obtained in other researches we found a statistically positive correlation coefficient between dividend policy and company profitability, implying that if the return on equity decreases it will have a negative impact on the annual cash dividend per share over the book value of assets per share. We found a statistically negative correlation between leverage and dividend policy, which means that more leveraged companies are likely to pay lower dividends. There is a statistically negative correlation between liquidity and leverage, which indicates that the more liquid assets firms have, the less they are leveraged.

Table III shows the results of estimating regression model by investigating the relationship between dividend policy and the attributes of non-financial companies listed on the Bucharest Stock Exchange market.
Table 3. Estimated results of panel data analysis

\begin{tabular}{cccc}
\hline \hline Div & Coefficient & $\begin{array}{c}\text { Standard } \\
\text { Error }\end{array}$ & Probability \\
\hline Constant & 0.0472 & 0.0049 & 0.0000 \\
Size & -0.0012 & 0.0000 & 0.0000 \\
Leverage & -0.0630 & 0.0029 & 0.0000 \\
Growth & -0.0038 & 0.0015 & 0.0138 \\
Liquidity & 0.0005 & 0.0001 & 0.0007 \\
Profitability & 0.0038 & 0.0000 & 0.0000 \\
GDP & -0.0006 & 0.0001 & 0.000 \\
R $^{2}$ & 0.7947 & & \\
Adj. $\mathrm{R}^{2}$ & 0.7930 & & \\
& & &
\end{tabular}

The R-Squared represents a measure of the overall fitness of the model and specifies that the model is capable of explaining about $80 \%$ of the systematic variation in the dependent variable.

The empirical findings indicate that the firms' profitability have a positive impact on the dividend policy decisions of listed companies, which means that the firms with high profits show an increase in the propensity to pay dividends more than less profitable companies. This is in line with I. Jabbouri [3], C.

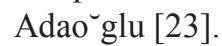

The analysis documents a negative relationship between size and dividend policy, which means that the response of small companies' stock prices to dividend announcements is higher than the reaction of larger companies. This is in line with Z. Jin [24], but this result does not agree with the findings of I. Jabbouri [3], H. DeAngelo, L. DeAngelo, D.J. Skinner [13] where they mentioned the fact that firm size is positively associated with dividend payout.

Consistent with previous findings, the study reports a negative relationship between financial leverage and dividend policy I. Jabbouri [3], D.L. Papadopoulos, P.D. Charalambidis [4]. Thus, more financially indebted firms may decrease dividend payments.

Furthermore, empirical findings from the regression analysis on the relationship between growth and the dividend payout of listed firms indicate that there is an inverse relationship, which can be explained by the fact that investment opportunities would deplete cash resources available for dividend payments. This is in line with the findings of I. Jabbouri [3].

As expected, the study reveals a positive relationship between company's liquidity and dividend policy. The result is similar with prior findings, companies facing liquidity risk are unlikely to issue dividends $\mathrm{H}$. DeAngelo, L. DeAngelo, D.J. Skinner [13], I. Jabbouri [3].

Finally, in addition to the aforementioned findings, table III also shows the result on the relationship between state of the economy and the dividend payouts decisions of listed firms. Regression analysis result shows that there is a negative relationship between the state of the economy (proxied by GDP growth rate) and the dividend policy decisions of listed firms in Romania. The international economic crisis had a significant impact over Romanian capital market C.E Stoenoiu, A. Nedelcut 
[25], I.A. Iancu [26]. The result specify that management tends to increase dividend payments in periods of economic downturns and decrease them in good economic times, which is in line with I. Jabbouri [3].

For detecting the multi-collinearity among predictors in the multiple regression model, the Variance Inflation Factors (VIF) for explanatory variables were determined and presented in Table IV.

Table 4. Variance inflation factors

\begin{tabular}{cc}
\hline \hline Variable & VIF \\
\hline Size & 1.04 \\
Leverage & 1.40 \\
Growth & 1.06 \\
Liquidity & 1.35 \\
Profitability & 1.06 \\
GDP & 1.06
\end{tabular}

All the VIF are relatively small and none of them is greater than 1.4. Thus, there is no problem of multicollinearity, which means there is not necessary to reduce the collinearity by eliminating variables from the analysis.

\section{Conclusions}

This paper examines the main determinants of dividend policy using a sample of Romanian nonfinancial companies listed on the Bucharest Stock Exchange market between 2007 and 2016. The study noticed that there was a positive association between the profitability of firms and dividend payout of companies. The paper, also, validates the positive relationship between firm's liquidity and dividend policy. Thus, firms with a lack of liquidity are unlikely to distribute dividends. The paper revealed that there is a negative relationship between firms' financial leverage and the dividend payouts decisions of listed firms. Thus, riskier and more financially indebted companies are likely to pay lower dividends. Likewise, growth, firm size, and the state of the economy are negatively related to dividend policy. The results of this paper are useful for academics, analysts, investors, and regulators in emerging markets.

\section{References}

[1] 1. K. Kato, U. Loewenstein, W. Tsay, „Voluntary dividend announcements in Japan", PAC-BASIN FINANC J., 5, pp. 167193, 1997.

[2] M. Miller and F. Modigliani, "Dividend policy, growth, and the valuation of shares", J BUS, 34, pp. 411-433, 1961.
[3] I. Jabbouri, "Determinants of corporate dividend policy in emerging markets: Evidence from MENA stock markets", RES INT BUS FINANC, 37. pp. 283-298, 2016.

[4] D.L. Papadopoulos, P.D. Charalambidis, "Focus on present status and determinants of dividend payout policy: Athens stock exchange in perspective", $J$ FINANC MANAG ANAL, 20 (2), pp. 24-37, 2007.

[5] A. Fatemi, R. Bildik, "Yes: dividends are disappearing: worldwide evidence", J BANK FINANC, 36, pp. 662-677, 2012.

[6] H.K. Bakera, E. Kilincarslanb, A.H. Arsalc, "Dividend policy in Turkey: Survey evidence from Borsa Istanbul”, GLOB FINANC J, to be published.

[7] E.F. Fama, K.R. French, "Disappearing dividends: Changing firm characteristics or lower propensity to pay?", J FINANC ECON, 60 , pp. 3-43, 2001.

[8] D.J. Denis, I. Osobov, "Why do firms pay dividends? International evidence on the determinants of dividend policy, $J$ FINANC ECON, 89, pp. 62-82, 2008.

[9] L. Renneboog, G. Trojanawski, "Patterns in payout policy and payout channel choice of UK firms in the 1990s, ECGI Working Paper Series in Finance, 34, pp. 411-433, 2005.

[10] H. Von Eije, W.L. Megginson, ,Dividends and share repurchases in the European Union", J FINANC ECON, 89, pp. 347-374, 2008.

[11] Y.S. Reddy, S. Rath, "Disappearing dividends in emerging markets: Evidence from India", EMERG MARK FINANC TR, 41, pp. 58-82, 2005.

[12] S.P. Ferris, N. Jayaraman, S. Sabherwal, "Catering effects in corporate dividend policy: International evidence", $J$ BANK FINANC, 33, pp. 1730-1738, 2009.

[13] H. DeAngelo, L. DeAngelo, D.J. Skinner, "Are dividends disappearing? Dividend concentration and the consolidation of earnings", J FINANC ECON, 72, pp. 425-456, 2004.

[14] B. Julio, D. Ikenberry, „Reappearing dividends”, J APPL CORP FINAN, 16(4), pp. 89-100, 2004.

[15] R. Bildik, A. Fatemi, I. Fooladi, "Global dividend payout patterns: The US and the rest of the world and the effect of financial crisis", GLOBAL FINANCE J, 28, pp. 38-67, 2015.

[16] G. Bekaert, C.R. Harvey, "Foreign speculators and emerging equity markets", J FINANC, 55, pp. 565-614, 2000.

[17] T. Lagoarde-Segot, "Firms and markets behaviours in emerging markets", RES INT BUS FINANC, 27, pp. 145-146, 2013.

[18] H.K. Baker, G.E. Farrelly, E.T. Veit, "Revisiting managerial perspectives on dividend policy", J ECON FINANC, 26, pp. 267283, 2002.

[19] A. Hafeez, Y.J. Attiya, "The determinants of dividend policy in Pakistan", INT RES J FINANC ECON, 25, pp. 148-171, 2009.

[20] K. Li, X. Zhao, "Asymmetric information and dividend policy", FINANC MANAGE, 34, pp. 673-694, 2008.

[21] Y. Grinstein, R. Michaely, „Institutional holdings and payout policy", J FINANC, 60, pp. 1389-1426, 2005.

[22] J. Benavides, L. Berggrun, H. Perafan, "Dividend payout policies: Evidence from Latin America", FINANC RES LETT, 17, pp. 197-210, 2016

[23] C. Adao glu, "Instability in the dividend policy of the Istanbul stock exchange (ISE) corporations: evidence from an emerging market", EMERG MARK REV, 1(3), pp. 252-270, 2000.

[24] Z. Jin, "On the differential market reaction to dividend initiations", Q REV ECON FINANC, 12, pp. 263-277, 2000.

[25] C.E Stoenoiu, A. Nedelcut, "The economic crisis in the context of globalization", J. Int. Sci. Publ. : Econ. Bus., 7(1), pp. 195-207, 2013.

[26] I.A. Iancu, "Investing Strategies of Romanian Retail Investors Before and During the Crisis (2006-2009)", SEA-Practical Application on Science, III (9), 23-28, 2015. 